\title{
Sinking export of particulate organic material from the euphotic zone in the eastern Beaufort Sea
}

\author{
Thomas Juul-Pedersen ${ }^{1,2,3, *}$, Christine Michel ${ }^{1}{ }$ Michel Gosselin $^{2}$ \\ ${ }^{1}$ Freshwater Institute, Fisheries and Oceans Canada, 501 University Crescent, Winnipeg, Manitoba R3T 2N6, Canada \\ ${ }^{2}$ Institut des sciences de la mer (ISMER), Université du Québec à Rimouski, 310 Allée des Ursulines, Rimouski, \\ Québec G5L 3A1, Canada \\ ${ }^{3}$ Present address: Greenland Climate Research Centre, Greenland Institute of Natural Resources, PO Box 570 , \\ DK-3900 Nuuk, Greenland
}

\begin{abstract}
This paper presents an extensive spatial and temporal study of the sinking export of particulate organic material below the euphotic zone in the eastern Beaufort Sea. Free-drifting shortterm particle interceptor traps were deployed, generally at $50 \mathrm{~m}$, during fall 2002 and 2003, and summer 2004. The different regions of the sampling area, i.e. the Amundsen Gulf and the Mackenzie shelf and slope, showed similar ranges in the sinking export of chlorophyll a (chl a) and particulate organic carbon (POC) in fall, while regional differences were observed in summer. The 2 regions showed a general decreasing trend in sinking fluxes towards fall. The highest chl $a$ and POC sinking fluxes during this study were therefore recorded during summer $\left(3.6\right.$ and $258 \mathrm{mg} \mathrm{m}^{-2} \mathrm{~d}^{-1}$, respectively). A high retention of suspended biomass was observed throughout this study, i.e. low daily loss rates of suspended chl $a$ and POC (both averaging ca. $1 \% \mathrm{~d}^{-1}$ ) were observed. Still, the POC sinking export accounted for, on average, half of the particulate primary production throughout this study. Zooplankton, primarily copepods, played an important role in the sinking export of particulate organic material, particularly in the Amundsen Gulf. A cluster-based analysis of the sinking protist cell assemblage revealed a seasonal succession that prevailed over spatial and interannual differences between the stations sampled in the eastern Beaufort Sea. Flagellates dominated throughout the study area, while diatoms, dominated by Fragilariopsis cylindrus, showed a decreasing contribution to the sinking protist cell assemblage towards fall. The presence of the sea ice related pennate diatoms Nitzschia frigida and Navicula vanhoeffenii in the material collected during summer reflected an input of organic material from sea ice. Results from particle interceptor traps deployed at a station in Franklin Bay during ice-covered and ice-free conditions showed the importance of taking into account under-ice sinking fluxes (up to $115 \mathrm{mg} \mathrm{C} \mathrm{m}^{-2} \mathrm{~d}^{-1}$ for POC) for sinking export estimates on Arctic shelves.
\end{abstract}

KEY WORDS: Arctic $\cdot$ Beaufort Sea $\cdot$ Sedimentation $\cdot$ Particulate organic matter $\cdot$ Phytoplankton Fecal pellets $\cdot$ Carbon $\cdot$ Sea ice $\cdot$ Shelf

\section{INTRODUCTION}

The extent and thickness of the sea ice cover have changed in the Northern Hemisphere during the last 3 decades; these changes are thought to be a consequence of the ongoing global warming trend (IPCC 2007). The extent of multi-year sea ice, primarily found in the central Arctic Ocean, has been decreasing by ca. $7 \%$ per decade since 1978 (IPCC 2007), as multiyear sea ice is being replaced by seasonal first-year sea ice in many areas (e.g. Belchansky et al. 2005, Maslanik et al. 2007). Moreover, the number and size of sea ice flaw leads and polynyas in the Arctic Ocean are expected to increase if the climate change trend 
continues (ACIA 2005). Consequently, the duration and extent of seasonally ice-free areas are expected to increase in the Arctic Ocean, in particular in the coastal regions (ACIA 2005, IPCC 2007).

Changes in sea ice dynamics may have impacts on marine productivity and ecosystem structure, especially on Arctic continental shelves (e.g. Grebmeier et al. 2006) which comprise a large part of the Arctic Ocean (i.e. $53 \%$ of the total surface area; Jakobsson 2002). An increase in the duration and extent of icefree areas is likely to improve conditions for phytoplankton production in the Arctic Ocean, due to increased light availability in the upper water column (ACIA 2005). Phytoplankton production already contributes ca. 75 to $>97 \%$ of the total annual primary production (i.e. ice algal and phytoplankton production) on Arctic shelves (Subba Rao \& Platt 1984, Legendre et al. 1992, Gosselin et al. 1997).

Spring phytoplankton production on Arctic shelves, which is often dominated by diatoms, is generally associated with the moving ice edge during spring melt, as the upper water column is stabilized via the halocline formed by released melt water (e.g. Sakshaug \& Skjoldal 1989, Carmack et al. 2006). Ice edge blooms or spring blooms in polynyas are often terminated by nutrient limitation within the surface mixed layer (e.g. Sakshaug \& Skjoldal 1989, Carmack et al. 2006, Tremblay et al. 2006, Mundy et al. 2009). Nutrient limitation often induces a succession in phytoplankton species, from diatoms to flagellates and dinoflagellates (e.g. Rat'kova et al. 1998, Dale et al. 1999, Hill \& Cota 2005). A phytoplankton bloom can occur during fall in Arctic areas, as wind mixing can reintroduce nutrients into the surface mixed layer (e.g. Klein et al. 2002, Arrigo \& van Dijken 2004, Carmack et al. 2006).

Primary produced organic material may be vertically exported to the benthos as intact algal cells, or it may be diverted through the pelagic heterotrophic food web (e.g. Turner 2002, Wassmann et al. 2006). Sinking of intact algal cells generally conveys organic material of a high quality to the benthos, while algal material diverted through the heterotrophic food web results in a reduced sinking export of organic material of usually lesser quality (e.g. Turner 2002). Herbivorous grazers, particularly copepods, may at times effectively graze on suspended algal material in some Arctic areas (e.g. Michel et al. 1996, Fortier et al. 2002, Forest et al. 2007). Fecal pellets from herbivorous grazers may therefore at times represent an important component of the vertically exported organic material (e.g. up to ca. $60 \%$ of POC sinking fluxes; Juul-Pedersen et al. 2006). A potential increase in the annual primary production in the Arctic Ocean associated with climate changes (ACIA 2005, Arrigo et al. 2008), accompanied by changes in the pelagic heterotrophic food web
(Grebmeier et al. 2006), will likely result in changes to the pelagic-benthic coupling on the Arctic continental shelves.

This study investigates spatial and temporal variability in the sinking export of particulate organic material from the euphotic zone in the eastern Beaufort Sea. The objectives of this study were to (1) assess spatial variations in the magnitude of the sinking export, (2) characterize any patterns in the composition of the sinking material within the sampling area, especially with respect to protist cell assemblages, and (3) compare the magnitude of the sinking export of particulate organic material during sea ice-covered and subsequent ice-free conditions at a station in Franklin Bay. Our first hypothesis was that the eastern Beaufort Sea would display spatial and temporal differences, from spring to fall, in the magnitude of the sinking export of particulate organic material. We also hypothesized that higher sinking fluxes of organic material would be observed in ice-free compared to ice-covered conditions, as phytoplankton may be exported from the euphotic zone.

\section{MATERIALS AND METHODS}

Study area. This study was conducted during a multi-year sampling program of the Canadian Arctic Shelf Exchange Study (CASES) in the eastern Beaufort Sea, during fall 2002 and 2003 and summer 2004 (Table 1, Fig. 1). The sector of the Beaufort Sea studied here covers 2 distinctive regions, i.e. the Mackenzie shelf and slope, and the Amundsen Gulf. The Mackenzie shelf extends ca. $120 \mathrm{~km}$ offshore and ca. $530 \mathrm{~km}$ along the Tuktoyaktuk peninsula until the Cape Bathurst peninsula (ca. $6.0 \times 10^{4} \mathrm{~km}^{2}$; Carmack et al. 2004; Fig. 1). Landfast first-year sea ice generally covers the inshore part of the Mackenzie shelf (until the ca. $20 \mathrm{~m}$ isobath) from December to May/June (Carmack \& Macdonald 2002). A flaw lead system which separates the landfast sea ice from offshore drifting pack-ice generally develops into the recurring Cape Bathurst Polynya protruding into the Amundsen Gulf (Barber \& Hanesiak 2004). The polynya generally starts forming during May, and the sea ice continues to retreat during summer leading to largely ice-free conditions in the Amundsen Gulf by August (Barber \& Hanesiak 2004). Consequently, phytoplankton production initiates about a month earlier on the outer parts of the Mackenzie Shelf compared to the inner parts, due to the retreating sea ice (Carmack et al. 2004). As nutrients are depleted in the surface waters following spring, a deep chlorophyll a (chl a) maximum forms on the Mackenzie Shelf during summer (Carmack et al. 2004). Although most phytoplankton production 


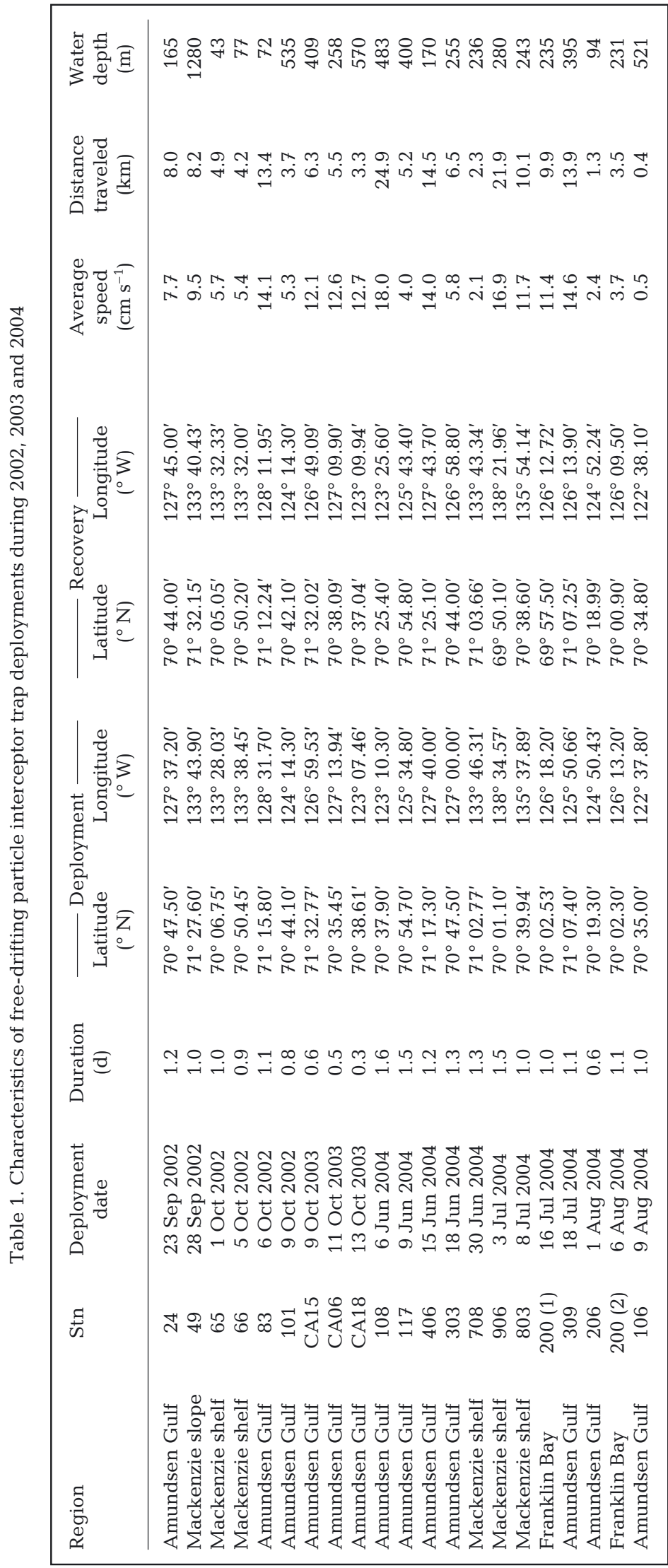

occurs during spring and summer, a considerable production has been reported during autumn in this region (Brugel et al. 2009). The Mackenzie shelf is strongly influenced by the Mackenzie River, which has the highest sediment discharge of the rivers entering the Arctic Ocean (Macdonald et al. 1998). The Mackenzie River has been shown to have a strong influence on sinking fluxes of particulate material in the plume area (Macdonald et al. 1998, O'Brien et al. 2006, Juul-Pedersen et al. 2008b).

Sampling. Sampling was carried out from the icebreakers CCGS 'Pierre Radisson' (in 2002) and CCGS 'Amundsen' (in 2003 and 2004). Sinking fluxes of particulate material were measured at 21 stations using short-term (1.0 \pm $0.3 \mathrm{~d}$, see Table 1) free-drifting particle interceptor traps. The only deployments longer than $1.6 \mathrm{~d}$ were during under-ice sampling at the Franklin Bay station; see description below. Traps were deployed at depths ranging from 15 to $150 \mathrm{~m}$ during this sampling. The focus of the present paper is on results from $50 \mathrm{~m}$, except for shallow Stns 65 \& 83, and Stn 106 where traps were deployed at 25 and $75 \mathrm{~m}$, respectively. The free-drifting trap deployments were all below the euphotic zone which is defined in the present study as the depth receiving $1 \%$ of surface irradiance. At each station, the euphotic zone depth was estimated from a downwelling photosynthetically active radiation underwater profile (QCP-2300, Biospherical Instruments). The euphotic zone depth ranged from 10 to $60 \mathrm{~m}$, with an average of $37 \mathrm{~m}$. The euphotic zone depth was $>50 \mathrm{~m}$ at 4 of the stations visited. We were able to estimate a potential bias in sinking flux measurements that would result from the positioning of particle interceptor traps relative to the euphotic zone depth for these stations. On average, there was a $14 \%$ variability between POC sinking fluxes measured at $50 \mathrm{~m}$ and those measured just below the euphotic zone.

Duplicate particle interceptor traps were deployed at the sampling depth. A wave dampening device comprised of a series of 7 floaters, of which 3 were submerged, was arranged on the free-drifting trap arrays. The submerged floaters increased water resistance of the array, thereby reducing the vertical movement of the particle interceptor traps attached to the drifting line. The traps were made of polyvinyl chloride (PVC) cylinders closed at one end, with an internal diameter of $10 \mathrm{~cm}$ and an aspect ratio (height:diameter) of 7 . A CAST 


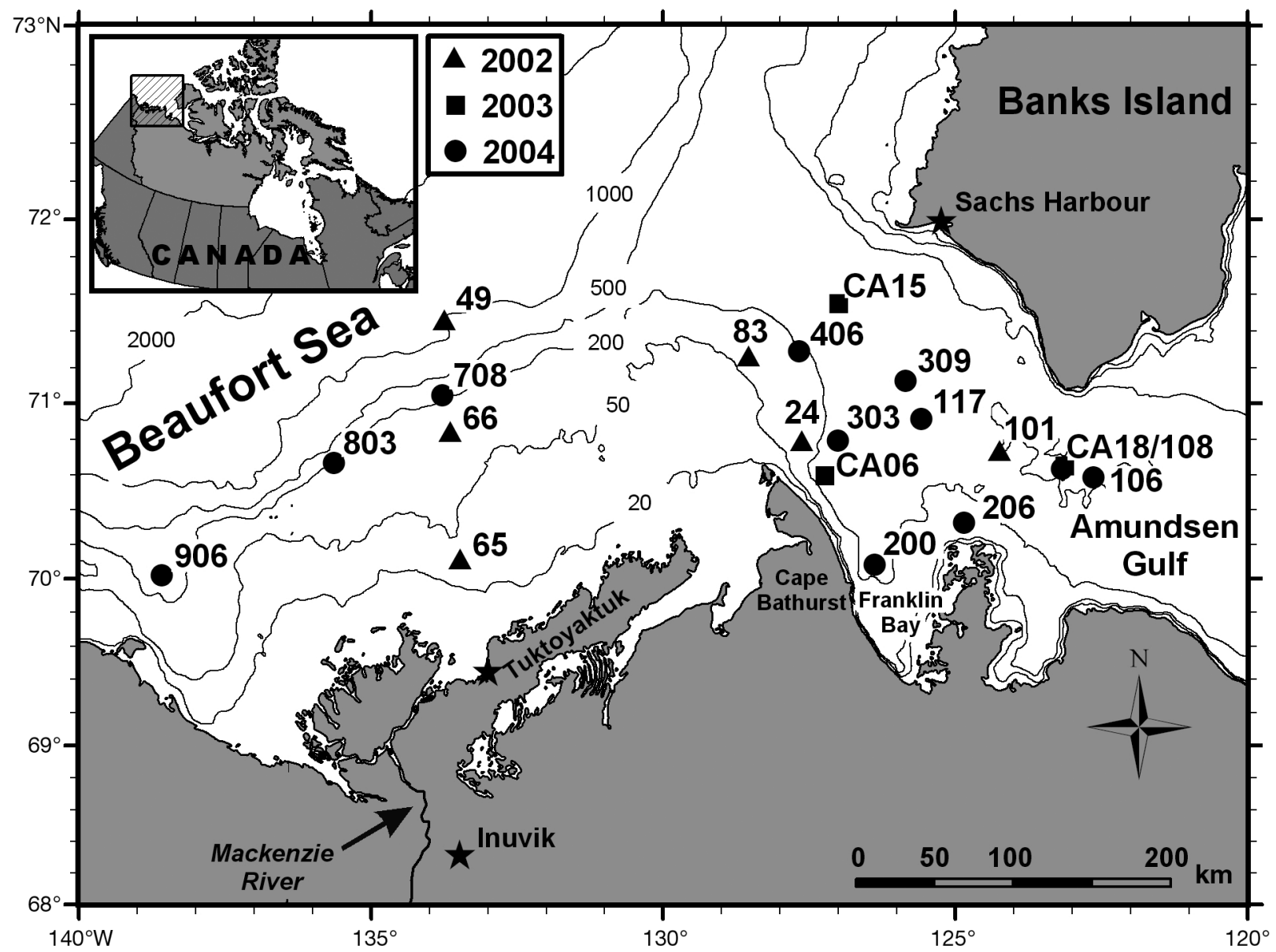

Fig. 1. Location of the sampling stations in the eastern Beaufort Sea, in fall 2002 and 2003 and summer 2004. Depth contours in m

ARGOS drifter buoy (Seimac Smart Cat PTT / GPS transmitter) and a Novatech Designs RF-700C1 radio beacon were used to track the position of the freedrifting trap arrays.

Sampling by particle interceptor traps was carried out in accordance with Joint Global Ocean Flux Study (JGOFS) protocols (Knap et al. 1996) and recommendations by Gardner (2000). The particle interceptor traps were filled with filtered $(0.22 \mu \mathrm{m})$ seawater collected at depths $>200 \mathrm{~m}$ prior to deployment, to ensure that the higher density particle-free water remained inside the traps. Upon recovery, the traps were fitted with a clean lid and set aside for sedimentation for $8 \mathrm{~h}$ in a cold room $\left(0^{\circ} \mathrm{C}\right)$ onboard the ship. The supernatant was gently removed after the sedimentation period and the remaining sample was pre-screened $(425 \mu \mathrm{m})$ to remove large swimmers. Duplicate particle interceptor trap samples were pooled together, their volume measured, and the samples were stored in dark containers for analyses.

Particle interceptor traps were also deployed at a station in Franklin Bay (Stn 200; Fig. 1) experiencing sea- sonal landfast first-year sea ice cover on 16 consecutive occasions from 23 February to 20 June 2004. The trap array was fixed to the sea ice with traps deployed at $25 \mathrm{~m}$ under the sea ice for, on average, $7.8 \pm 0.8 \mathrm{~d}(\mathrm{n}=$ 6) from 23 February to 13 April and $6.2 \pm 0.4 \mathrm{~d}(\mathrm{n}=8)$ from 13 April to 20 June, except for 2 deployments of 4.0 and $15.2 \mathrm{~d}$ on 26 May and 30 May, respectively. Upon recovery, the entire volume of the under-ice particle interceptor traps were pre-screened $(425 \mu \mathrm{m})$ to remove large swimmers and measured, and was stored in black containers for analyses (see Juul-Pedersen et al. 2008b for further details).

Sampling of the suspended material was carried out at each station with a rosette sampler equipped with 121 bottles (OceanTest Equipment) deployed at 3 to 8 depths within the upper $50 \mathrm{~m}$.

Analyses. Trap samples were gently mixed prior to subsampling. This method has proved to provide repeatable results, as the average intra-trap percent variability has been estimated at $7.8 \%$ for chl a using similar particle interceptor traps and methods. To ensure minimal disturbance of the collected material, 
samples for microscopic examination were taken first. Subsamples for fecal pellet (100 to $250 \mathrm{ml}$ ) and protist (100 to $250 \mathrm{ml}$ ) analyses were preserved with $2 \%(\mathrm{v} / \mathrm{v})$ buffered formaldehyde and $1 \%$ (v/v) acidic Lugol's solution, respectively. Enumeration and measurement (length and width) of fecal pellet dimensions were later conducted using a Carl Zeiss inverted microscope (100× magnification). Fecal pellets were classified according to type (cylindrical or elliptical) and condition (intact or broken). The volume of intact and broken cylindrical fecal pellets was calculated using the equations for a cylinder with half-spherical ends and for a cylinder, respectively. The volume of intact elliptical fecal pellets was calculated using the equation for an ellipsoid; no broken elliptical fecal pellets were observed during the present study. Fecal pellet-based carbon (FPC) was estimated using a volume to carbon conversion factor of $0.057 \mathrm{pg} \mathrm{C} \mathrm{mm}^{-3}$ for cylindrical (i.e. copepod) fecal pellets and $0.042 \mathrm{pg} \mathrm{C} \mathrm{mm}^{-3}$ for elliptical (i.e. appendicularian) fecal pellets (González et al. 1994). Identification and enumeration of phytoplankton and other protists were conducted using a Leica DM IRB inverted microscope (400× magnification), according to the method of Lund et al. (1958). For each sample, a minimum of 300 cells was counted.

Chl $a$ and phaeopigments were measured on subsamples (50 to $200 \mathrm{ml}$ ) filtered onto Whatman GF/F $25 \mathrm{~mm}$ glass fiber filters. Pigments were extracted in $90 \%$ acetone for $24 \mathrm{~h}$ in cold dark conditions $\left(4^{\circ} \mathrm{C}\right)$. Samples were then analyzed on a Turner Designs 10AU fluorometer, using $90 \%$ acetone as a blank. The pigment concentration in the samples was calculated in accordance with Parsons et al. (1984).

Total particulate carbon (TPC) and particulate organic carbon (POC) were measured in subsamples (50 to $900 \mathrm{ml}$ ) filtered onto precombusted $\left(450^{\circ} \mathrm{C}\right.$ for $24 \mathrm{~h})$ Whatman GF/F $21 \mathrm{~mm}$ filters. The filters were dried at $60^{\circ} \mathrm{C}$ for $24 \mathrm{~h}$ and stored in separate Petri dishes. Filters for POC determination were acidified for $24 \mathrm{~h}$ in a desiccator saturated with $\mathrm{HCl}$ fumes, thereby removing any inorganic carbon. Analyses were conducted on a Perkin-Elmer Model 2400 CHN Analyzer. POC analysis was unfortunately not conducted at several stations in the Amundsen Gulf during the study (Stns CA15 \& CA18 during fall 2003; Stns 108, 117 and 303 during summer 2004). Missing POC data at these stations were extrapolated from the measured TPC sinking fluxes, using the strong linear regression between sinking fluxes of POC $(y)$ and TPC $(x)$ at other stations $\left(y=0.84 x+1.69 ; r^{2}=0.87 ; p<\right.$ 0.001). Unfortunately both TPC and POC data are missing from Stn 406.

The suspended material from the water column was analyzed for chl $a$ and POC as described above, although different sample volumes were used (S. Brugel pers. comm.). In addition, particulate phytoplankton production was measured by our CASES collaborators at some stations during trap deployments (Brugel et al. 2009). The method is described in detail in Brugel et al. (2009). Briefly, particulate phytoplankton production was measured at 5 optical depths $(100,50,25,10$ and $1 \%$ of surface irradiance) with the ${ }^{14} \mathrm{C}$-uptake method in accordance with JGOFS protocols (Knap et al. 1996). After $24 \mathrm{~h}$ on-deck in situ simulated incubation, samples were filtered onto Whatman GF/F filters. The filters were placed in borosilicate scintillation vials and acidified overnight with $0.5 \mathrm{~N} \mathrm{HCl}$, in order to remove ${ }^{14} \mathrm{C}$ that was not incorporated (Lean \& Burnison 1979). Scintillation cocktail was then added to the vials. The vials were stored in the dark for $24 \mathrm{~h}$ before being counted on a Packard Tri-Carb 2900 TR Liquid Scintillation Analyzer. Particulate primary production corrected for dark uptake was calculated according to Knap et al. (1996).

Calculations and statistical analyses. The sinking flux of the measured variables was calculated using the following equation:

$$
\begin{aligned}
& \text { Sinking flux }\left(\mathrm{mg} \mathrm{m}^{-2} \mathrm{~d}^{-1}\right)= \\
& \left(C_{\text {trap }} \times V_{\text {trap }}\right) /\left(A_{\text {trap }} \times T_{\text {dep }}\right)
\end{aligned}
$$

where $C_{\text {trap }}\left(\mathrm{mg} \mathrm{m}^{-3}\right)$ is the concentration of the measured variable in the particle interceptor trap, $V_{\text {trap }}\left(\mathrm{m}^{3}\right)$ is the volume of the particle interceptor trap sample, $A_{\text {trap }}\left(\mathrm{m}^{2}\right)$ is the particle interceptor trap surface area and $T_{\text {dep }}(d)$ is the deployment time.

The daily loss rate of suspended chl $a$ and POC biomass in a given depth stratum due to sinking export was estimated using the following equation:

$$
\begin{aligned}
& \text { Daily loss rate }\left(\% \mathrm{~d}^{-1}\right)= \\
& \text { Sinking flux } / C_{\mathrm{int}} \times 100
\end{aligned}
$$

where sinking flux is from Eq. (1), generally at $50 \mathrm{~m}$, and $C_{\text {int }}$ is the integrated biomass of chl $a$ and POC, generally in the upper $50 \mathrm{~m}$, estimated using chl $a$ and POC concentrations measured at 3 to 8 depths in the 0 to $50 \mathrm{~m}$ stratum.

The export ratio was calculated as the ratio of the POC sinking flux at a given depth (at $50 \mathrm{~m}$, except for Stns $65,83 \& 106$ ) to the particulate phytoplankton production integrated over the euphotic zone depth. This ratio is dimensionless.

A group-average linkage cluster analysis was performed to determine similarities in the absolute sinking flux of protist cell taxa (including empty diatom frustules and diatom spores) between stations, based on a Bray-Curtis similarity matrix computed on the logarithmically transformed $(\log (x+1))$ sinking cell numbers (Field et al. 1982, Legendre \& Legendre 1998). The difference between groups of sampling stations, at an arbitrarily level of similarity selected to obtain 
4 groups, was tested using Analysis of Similarities (1-way ANOSIM; Legendre \& Legendre 1998). The Global R value obtained provided an absolute measure of how separated the groups were on a scale of 0 (indistinguishable) to 1 (all similarities within groups are greater than similarities between groups) (Clarke \& Gorley 2001). The cluster analysis and ANOSIM were performed using the PRIMER software package (Clarke \& Gorley 2001).

Differences between 2 or more average values of sinking fluxes in groups of stations, of varying sample sizes, were analyzed using a 1-way ANOVA (Sokal \& Rohlf 1981).

\section{RESULTS}

Fig. 2 shows the chl $a$ and POC sinking fluxes measured in the 2 sampling regions, i.e. the Amundsen Gulf and the Mackenzie shelf and slope, in the eastern Beaufort Sea, during fall 2002 and 2003 and summer 2004. Sinking fluxes of chl $a$ and POC ranged from 0.04 to 0.22 and 14.8 to $77.5 \mathrm{mg} \mathrm{m}^{-2} \mathrm{~d}^{-1}$, respectively, during fall 2002 and 2003 (Fig. 2a-d, Table 2). Sinking fluxes of both chl $a$ and POC were generally higher during summer 2004 (Fig. 2e,f, Table 2) than during fall 2002 and 2003 (Fig. 2a-d, Table 2), although sample means were not statistically different (1-way ANOVA, p > 0.05). In addition, the sinking fluxes of POC in summer 2004 were generally higher on the Mackenzie shelf and slope than in the Amundsen Gulf (Fig. 2e,f, Table 2), although they were not statistically different (1-way ANOVA, p > 0.05). The highest chl $a$ and POC sinking fluxes recorded throughout this study were respectively measured at Stn 303 in the Amundsen Gulf and at Stn 906 on the Mackenzie shelf during summer 2004.

Cluster analysis of the sinking assemblage of autotrophic and heterotrophic protists (including empty diatom frustules and resting spores), at each sampling station, showed significant (1-way ANOSIM, similarity level $=43 \%$, Global $\mathrm{R}=0.76, \mathrm{p}<0.001$ ) similarity between the stations sampled in the eastern Beaufort Sea (Fig. 3). Based on the taxonomic composition of the sinking assemblage, 4 groups of stations were obtained. One group comprised stations visited during June 2004 (Group I: Stns 108, 117, 406 \& 303), while the stations sampled from July to August 2004 formed another distinctive group (Group II: Stns 708, 906, 803, 309, $106 \&$ 206). The stations sampled in September and October 2002 and 2003 formed another group (Group III: Stns CA15, CA18, CA06, 83, 24, 101, 49 \& 66), except for Stn 65 (October 2002) which constituted a separate group (Group IV).

Table 2. Sinking fluxes and daily loss rates of chlorophyll a (chl a), particulate organic carbon (POC), and export ratios at $50 \mathrm{~m}$ ( $25 \mathrm{~m}$ at Stns $83 \& 65$, and $75 \mathrm{~m}$ at Stn 106) during open water periods, in the eastern Beaufort Sea. The temporal grouping of stations in the Amundsen Gulf and on the Mackenzie shelf and slope is based on the cluster analysis (see Fig. 3). Averages and ranges of values are presented when applicable. NA: not available

\begin{tabular}{|c|c|c|c|c|c|c|c|}
\hline \multirow[t]{2}{*}{ Region } & \multirow[t]{2}{*}{ Period } & \multirow{2}{*}{ Group } & \multicolumn{2}{|c|}{ - Sinking flux } & \multicolumn{2}{|c|}{ — Daily loss rate — } & \multirow{2}{*}{$\begin{array}{c}\text { Export ratio } \\
(\%)\end{array}$} \\
\hline & & & $\begin{array}{c}\text { Chl a } \\
\left(\mathrm{mg} \mathrm{m}^{-2} \mathrm{~d}^{-1}\right)\end{array}$ & $\begin{array}{c}\text { POC } \\
\left(\mathrm{mg} \mathrm{m}^{-2} \mathrm{~d}^{-1}\right)\end{array}$ & $\begin{array}{l}\text { Chl } a \\
\left(\% d^{-1}\right)\end{array}$ & $\begin{array}{l}\text { POC } \\
\left(\% \mathrm{~d}^{-1}\right)\end{array}$ & \\
\hline \multirow[t]{3}{*}{ Amundsen Gulf } & $\begin{array}{l}\text { June } \\
2004\end{array}$ & I & $\begin{array}{c}1.3 \\
0.06-3.6\end{array}$ & $\begin{array}{c}42.8 \\
18.2-89.3\end{array}$ & $\begin{array}{c}1.2 \\
0.53-2.5\end{array}$ & $\begin{array}{c}0.40 \\
0.36-0.45\end{array}$ & $\begin{array}{c}14.5 \\
5.2-21.1\end{array}$ \\
\hline & $\begin{array}{l}\text { July to August } \\
2004\end{array}$ & II & $\begin{array}{c}0.13 \\
0.05-0.20\end{array}$ & $\begin{array}{c}52.4 \\
36.0-67.0\end{array}$ & $\begin{array}{c}0.78 \\
0.31-1.2\end{array}$ & $\begin{array}{c}1.3 \\
1.2-1.3\end{array}$ & $\begin{array}{c}51.6 \\
40.1-57.8\end{array}$ \\
\hline & $\begin{array}{c}\text { September to October } \\
2002 \text { and } 2003\end{array}$ & III & $\begin{array}{c}0.10 \\
0.05-0.22\end{array}$ & $\begin{array}{c}58.9 \\
37.8-77.5\end{array}$ & $\begin{array}{c}0.43 \\
0.29-0.65\end{array}$ & $\begin{array}{c}0.72 \\
0.37-1.3\end{array}$ & $\begin{array}{c}65.4 \\
41.3-79.7\end{array}$ \\
\hline \multirow[t]{3}{*}{$\begin{array}{l}\text { Mackenzie shelf } \\
\text { and slope }\end{array}$} & $\begin{array}{l}\text { July to August } \\
2004\end{array}$ & II & $\begin{array}{c}0.86 \\
0.12-2.0\end{array}$ & $\begin{array}{c}156.3 \\
84.1-258.4\end{array}$ & $\begin{array}{c}2.8 \\
1.5-3.6\end{array}$ & $\begin{array}{c}2.9 \\
2.7-3.1\end{array}$ & NA \\
\hline & $\begin{array}{c}\text { September to October } \\
2002 \text { and } 2003\end{array}$ & III & $\begin{array}{c}0.10 \\
0.04-0.15\end{array}$ & $\begin{array}{c}42.5 \\
14.8-70.2\end{array}$ & $\begin{array}{c}0.54 \\
0.22-0.86\end{array}$ & $\begin{array}{c}0.96 \\
0.65-1.0\end{array}$ & NA \\
\hline & Stn 65 in fall 2002 & IV & 0.08 & 75.5 & 2.0 & 1.8 & NA \\
\hline \multirow[t]{2}{*}{ Franklin Bay } & July 2004 & & 0.13 & 113.5 & 0.78 & 2.7 & 97.2 \\
\hline & August 2004 & & 0.04 & 31.9 & 0.26 & 0.86 & 28.8 \\
\hline All regions & Average & & $\begin{array}{c}0.44 \\
0.04-3.6\end{array}$ & $\begin{array}{c}70.7 \\
14.8-258.4\end{array}$ & $\begin{array}{c}1.1 \\
0.26-3.6\end{array}$ & $\begin{array}{c}1.3 \\
0.22-3.1\end{array}$ & $\begin{array}{c}50.1 \\
5.2-97.2\end{array}$ \\
\hline
\end{tabular}



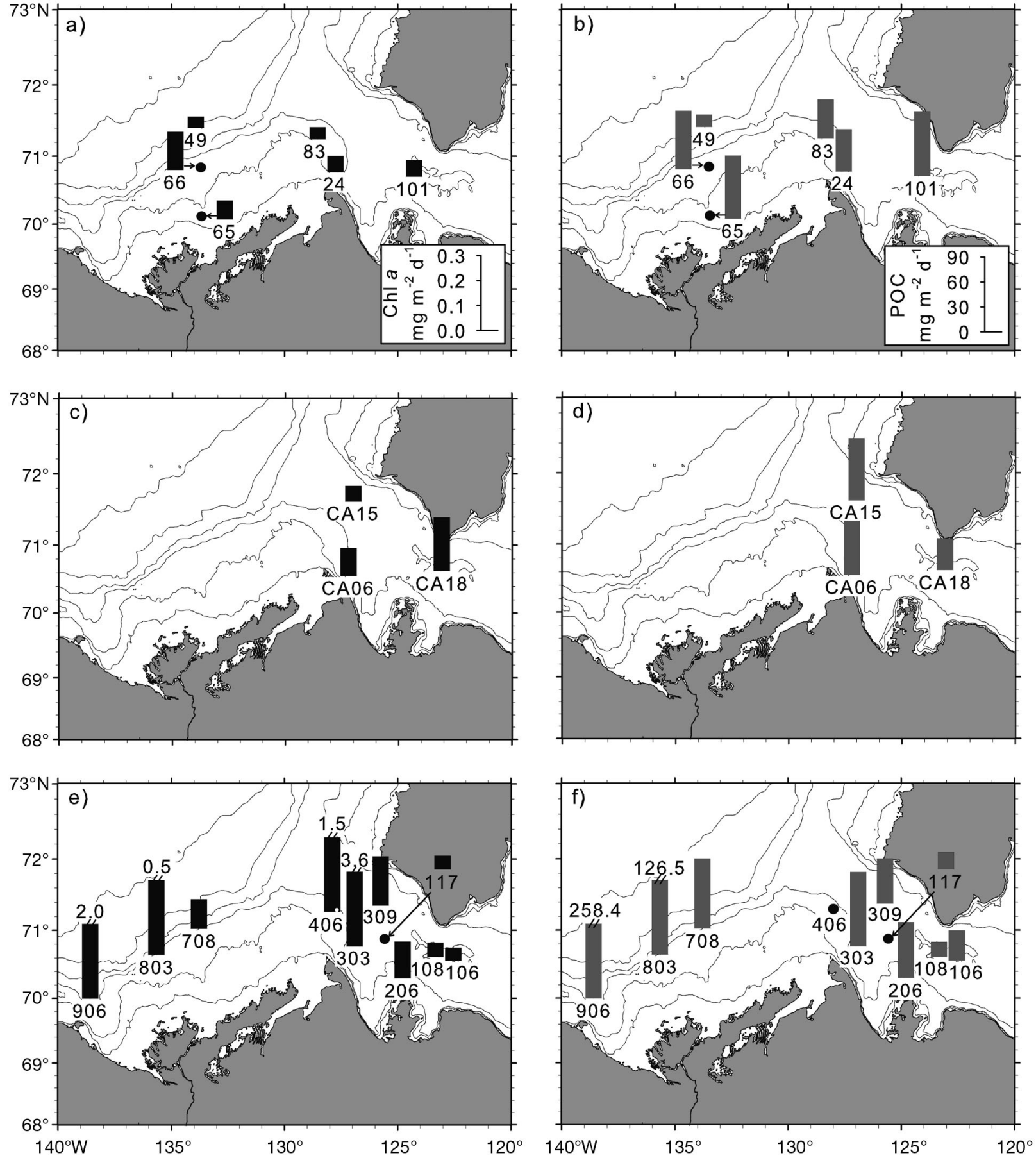

Fig. 2. Spatial variations in sinking fluxes of $(\mathrm{a}, \mathrm{c}, \mathrm{e})$ chlorophyll $a(\mathrm{chl} a)$ and $(\mathrm{b}, \mathrm{d}, \mathrm{f})$ particulate organic carbon (POC) during (a, b) fall 2002, (c, d) fall 2003, and (e, f) summer 2004 at $50 \mathrm{~m}$ (25 m at Stns 83 \& 65, and $75 \mathrm{~m}$ at Stn 106). Sinking fluxes exceeding the scales shown in $(\mathrm{a}, \mathrm{b})$ are presented above bars in $(\mathrm{e}, \mathrm{f})$

Fig. 4 presents the relative sinking flux of different protist groups (including autotrophs and heterotrophs), and dominant diatom species as well as the sinking flux of empty diatom frustules and diatom spores within the 4 groups of stations obtained from the cluster analysis. Flagellates were the dominant group of protists in the sinking cell assemblage in June and July to August (52.2 and $50.6 \%$ of the total cell sinking flux, respectively), and were even more abundant in September to October $(69.1 \%$ of the total cell 


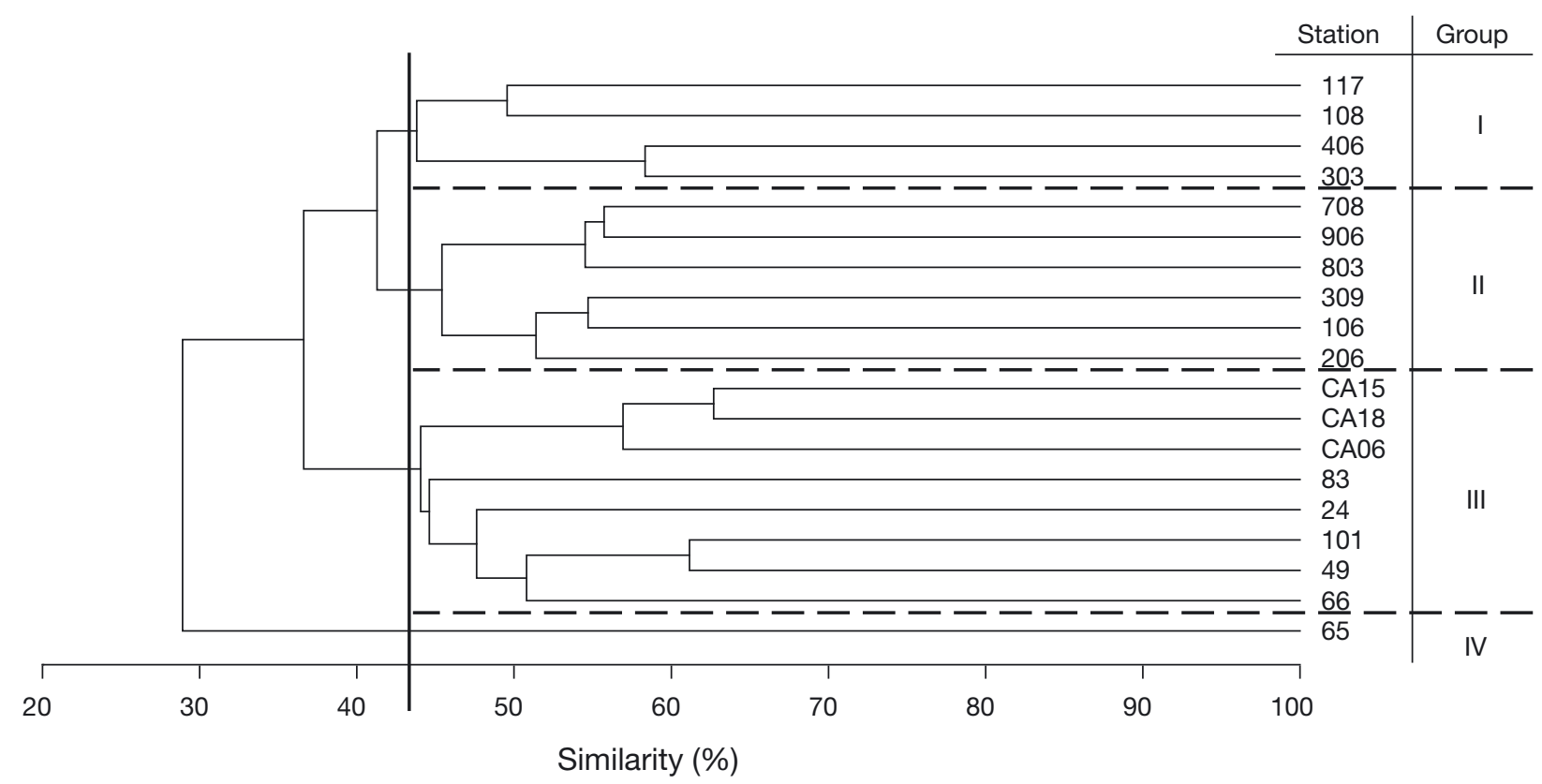

Fig. 3. Dendrogram obtained from group-average clustering of all sampling stations, in the eastern Beaufort Sea, based on the sinking fluxes of protistan cells at $50 \mathrm{~m}(25 \mathrm{~m}$ at Stns $83 \& 65$, and $75 \mathrm{~m}$ at $\mathrm{Stn} 106)$. Four groups of stations were formed at a similarity level of $43 \%$ (Global $\mathrm{R}=0.76, \mathrm{p}<0.001$ )

sinking flux; Fig. 4a). Pennate diatoms made up 30.3 and $34.0 \%$ of the total cell sinking flux, by numbers, in June and July to August, respectively. The maximum contribution of centric diatoms to the total cell sinking flux (i.e. 12.6\%) was observed in July to August. Dinoflagellates, ciliates and unidentified protists comprised $12.1 \%$ of the total cell sinking flux in June, while their contributions were negligible in July to August $(2.4 \%)$ and September to October $(2.5 \%)$. The contribution of pennate diatoms to total diatom sinking flux decreased from $77.0 \%$ in June to $49.9 \%$ in July to August (Fig. 4a), except at Stn 65 where the contribution of diatoms to total cell sinking flux was $<2 \%$ (Fig. 4a). The freshwater pennate diatom Eunotia sp. was the only identified diatom taxon in the material exported from the euphotic zone at Stn 65. The pennate diatom Fragilariopsis cylindrus was the dominant diatom species in June and July to August (36.0 and $50.7 \%$ of total diatom sinking flux, respectively), although other pennate diatoms contributed significantly in June $(28.7 \%$ of total diatom sinking flux; Fig. 4b). The pennate diatoms Nitzschia frigida and Navicula vanhoeffenii were present in the sinking diatom assemblage in June and July to August (together contributing 12.3 and $15.1 \%$ of total diatom sinking flux), while their contribution was negligible in September to October. Centric diatoms, such as Chaetoceros spp., showed a seasonally increasing contribution (from 23.1 to $50.1 \%$ of total diatom sinking flux from June to September-October), except at Stn 65. Average sinking fluxes of empty centric and pennate diatom frustules showed a seasonal decrease from June (30.2 and $258.4 \times 10^{6}$ cells m${ }^{-2} \mathrm{~d}^{-1}$, respectively) to September-October $\left(7.0\right.$ and $3.9 \times 10^{6}$ cells m${ }^{-2} \mathrm{~d}^{-1}$, respectively; Fig. 4c). Centric diatom spores were only present in July to August and September to October, and showed seasonally decreasing average sinking fluxes during these months (8.8 and $2.4 \times 10^{6} \mathrm{cells} \mathrm{m}^{-2}$ $\mathrm{d}^{-1}$, respectively).

Fig. 5 presents monthly-averaged sinking fluxes of organic material, from March to August, at $25 \mathrm{~m}$ at the station in Franklin Bay (Stn 200). Monthly averaged sinking fluxes of chl a increased significantly from March to June (1-way ANOVA, p < 0.01) and consistently decreased thereafter (Fig. 5a). Sinking fluxes of POC under the sea ice did not vary significantly from March to May (1-way ANOVA, p = 0.5), but increased rapidly in June (Fig. 5b). During the ice-free period (July and August), POC sinking fluxes remained high in July and decreased in August.

Table 2 summarizes the sinking fluxes and daily loss rates of chl $a$ and POC together with the export ratios, for each region, and according to the grouping obtained from the cluster analysis. For comparative purposes, this Table also reports observations at the station in Franklin Bay during the open water period. Average chl a sinking fluxes and chl a daily loss rates showed a temporal decrease in each region, although these trends were not statistically significant (1-way ANOVA, $p>0.05$ ). Average sinking fluxes of POC did not show any clear temporal trend in the Amundsen Gulf, but were higher in July to August than in Sep- 


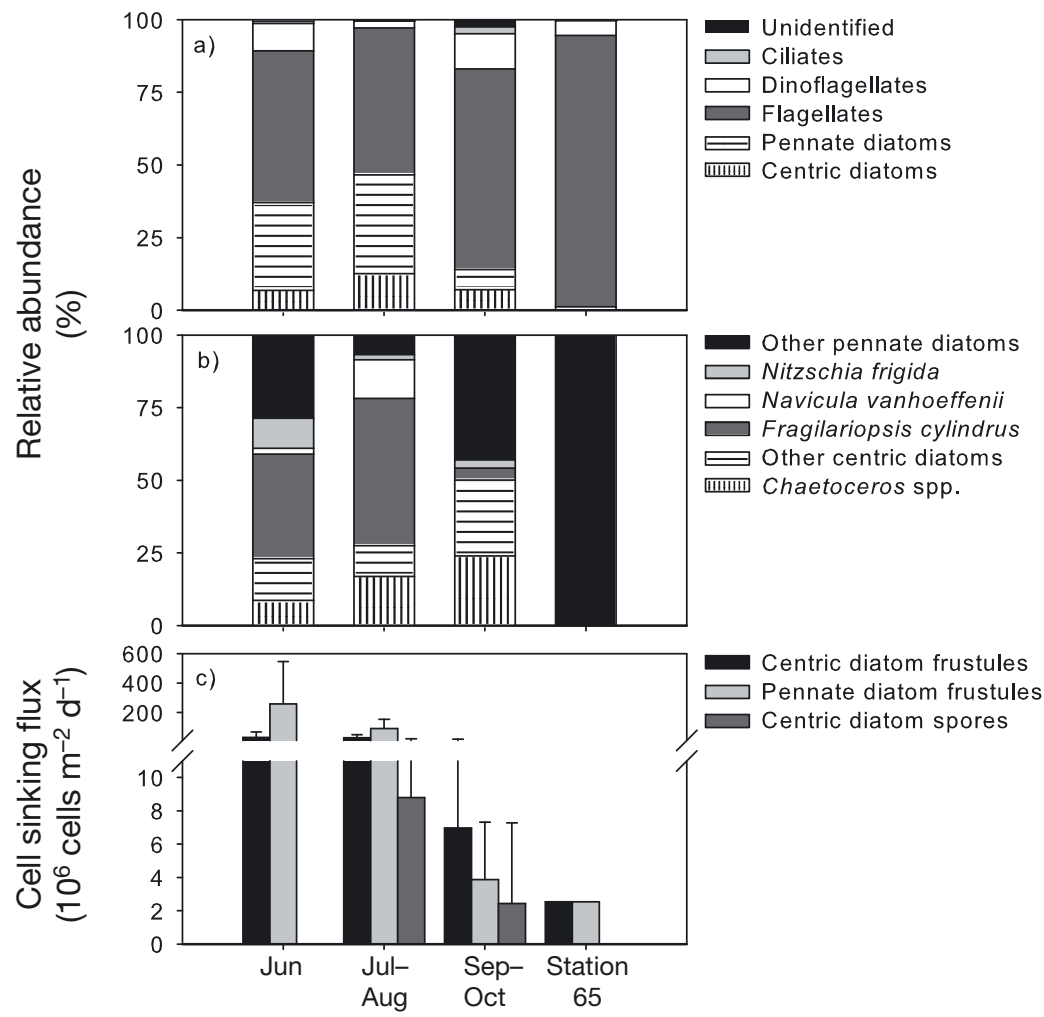

Fig. 4. Average relative sinking fluxes of (a) autotrophic and heterotrophic protist groups, (b) dominant diatom taxa, and (c) average sinking flux of empty diatom frustules and centric diatom spores at $50 \mathrm{~m}(25 \mathrm{~m}$ at Stns $83 \& 65$, and $75 \mathrm{~m}$ at Stn 106), for the 4 groups of stations with similar taxonomic composition in eastern Beaufort Sea. The grouping of stations is based on the cluster analysis

(see Fig. 3). In (c), bars represent standard deviations within each group

poral decrease in the Amundsen Gulf and on the Mackenzie shelf and slope, although the trends were not statistically significant (1-way ANOVA, p > 0.05). Similarly, in Franklin Bay, the sinking fluxes of cylindrical FPC and total FPC, as well as the contribution of FPC to total POC sinking fluxes, decreased from July to August.

\section{DISCUSSION}

\section{Sinking export in the eastern Beaufort Sea}

This multi-year study provides extensive regional coverage of the sinking export of chl $a$ and POC below the euphotic zone in the eastern Beaufort Sea. This sampling program covered most of the ice-free season in this area, which generally begins with initial sea ice break-up in late-April and lasts until freeze-up commences in late-October (e.g. Carmack \& Macdonald 2002, Barber \& Hanesiak 2004). While the broad spatial and temporal coverage of this study (21 stations over a wide area of the eastern Beaufort Sea over 3 yr) provides a unique and encompassing dataset on sinking export from the euphotic zone

tember to October on the Mackenzie shelf and slope. Moreover, average daily loss rates of POC in the Amundsen Gulf showed a significant (1-way ANOVA, $\mathrm{p}<0.001$ ) increase from June to July-August. In Franklin Bay, sinking fluxes of chl $a$ and POC were higher in July than August, whereas daily loss rates of suspended chl $a$ and POC decreased from July to August. The average export ratios increased significantly (1-way ANOVA, p < 0.01) throughout the open water period (i.e. from June to September-October) in the Amundsen Gulf, while it decreased from July to August in Franklin Bay. Primary production was unfortunately not measured on the Mackenzie shelf and slope during trap deployments.

Table 3 presents a summary of sinking fluxes of FPC and their contribution to total POC sinking fluxes according to the same grouping of stations as that of Table 2. Cylindrical fecal pellets were the main contributors to total FPC sinking fluxes in the eastern Beaufort Sea throughout the study (averaging 91.4\% of total FPC at all stations). Average sinking fluxes of cylindrical FPC and total FPC, and average contribution of FPC to total POC sinking fluxes, showed a tem- for this arctic area, it also underscores inherent challenges in dealing with intricate variability at multiple scales (i.e. regional, seasonal and interannual). Therefore, the various and combined effects of such variability need to be borne in mind as important factors driving, yet sometimes obscuring, some of the general trends observed. The 2 first sampling periods, September to October of 2002 and 2003, indicated little interannual change in the sinking export of particulate organic material in the fall, during this study, as a similar range of chl $a$ and POC sinking fluxes was observed in the eastern Beaufort Sea (Fig. 2, Table 2). These similarities support interannual comparisons within the present dataset. The subsequent sampling period, in summer 2004, suggests that the highest sinking fluxes of chl $a$ and POC occur early during the icefree period, June and July to August, in the eastern Beaufort Sea. This is in agreement with sinking export estimates from ${ }^{234} \mathrm{Th}$ deficits showing maximum deficits in June to July on the outer Mackenzie shelf (Amiel \& Cochran 2008). It has previously been shown that 2 key features, the Cape Bathurst Polynya and the Mackenzie River, which characterize this part of the 

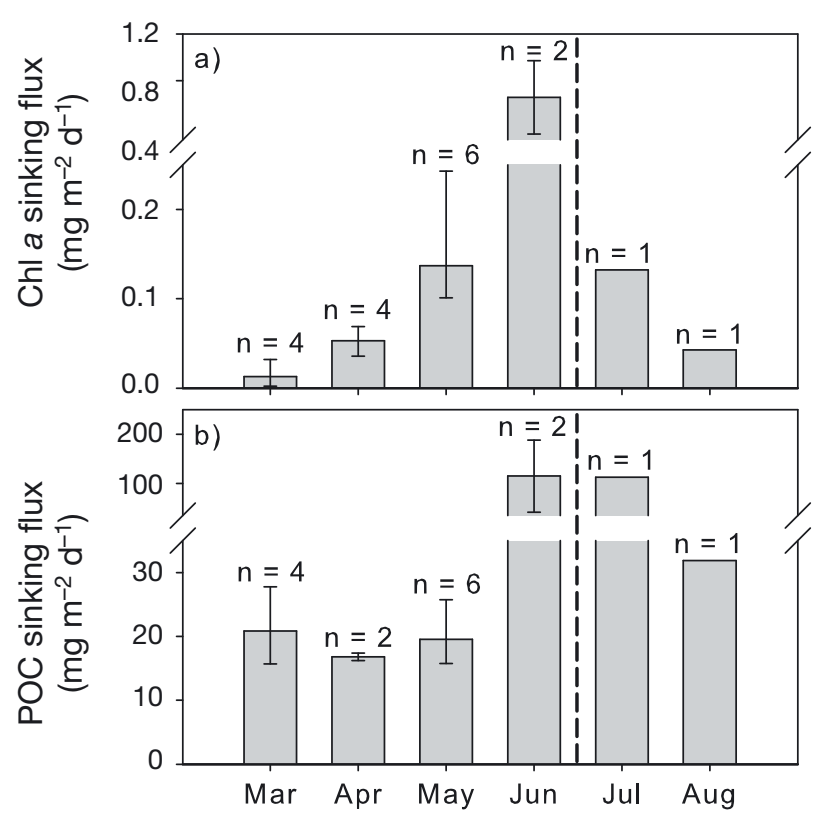

Fig. 5. Temporal variations in sinking fluxes of (a) chlorophyll a (chl a) and (b) particulate organic carbon (POC) at $25 \mathrm{~m}$ during under-ice sampling (March to June) and at $50 \mathrm{~m}$ during open water sampling (July and August) at a station in Franklin Bay (Stn 200). Monthly averaged fluxes are presented when applicable, with bars showing minimum and maximum fluxes. $\mathrm{n}$ : number of sampling points during each period. Vertical dashed line separates ice-covered and open water periods.
Beaufort Sea (e.g. Carmack \& Macdonald 2002, Amiel \& Cochran 2008), may induce high sinking fluxes of particulate organic material during spring and summer in this area (O'Brien et al. 2006, Amiel \& Cochran 2008, Juul-Pedersen et al. 2008b, Morata et al. 2008). While the isotopic composition of the sinking material was not obtained during this study, such an approach would likely have provided additional information on the exact origin of the collected material, as done by O'Brien et al. (2006) and Amiel \& Cochran (2008). High sinking fluxes of particulate organic material have been linked to spring phytoplankton production in polynyas (e.g. North Water Polynya [NOW]; Amiel et al. 2002, Michel et al. 2002, Caron et al. 2004) and increased river discharge during freshet in spring and summer (Dittmar \& Kattner 2003, Stein \& Macdonald 2004 and references therein, Carmack \& Wassmann 2006). The highest POC sinking export recorded in the eastern Beaufort Sea (Stn 906; Fig. 2f), during this study, was linked to a high sinking export of particulate organic material from the Mackenzie River plume in summer (2004), as described in detail in a companion study (Juul-Pedersen et al. 2008b).

The POC sinking fluxes observed throughout our multi-year sampling in the eastern Beaufort Sea (ranging from 14.8 to $258.4 \mathrm{mg} \mathrm{C} \mathrm{m}^{-2} \mathrm{~d}^{-1}$; Table 2) were persistently higher than previously reported sinking fluxes from the same shelf slope area $\left(<20 \mathrm{mg} \mathrm{C} \mathrm{m}^{-2}\right.$

Table 3. Sinking fluxes of fecal pellet-based carbon (FPC) and contribution of FPC to total particulate organic carbon (POC) sink-

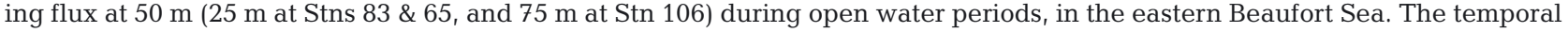
grouping of stations in the Amundsen Gulf and on the Mackenzie shelf and slope is based on the cluster analysis (see Fig. 3). Averages and ranges of values are presented when applicable

\begin{tabular}{|c|c|c|c|c|c|c|}
\hline Region & Period & Group & $\begin{array}{l}\text { Cylindrical } \\
\left(\mathrm{mg} \mathrm{m}^{-2} \mathrm{~d}^{-1}\right)\end{array}$ & $\begin{array}{c}\text { FPC Sinking flux } \\
\text { Elliptical } \\
\left(\mathrm{mg} \mathrm{m}^{-2} \mathrm{~d}^{-1}\right)\end{array}$ & $\begin{array}{c}\text { Total } \\
\left(\mathrm{mg} \mathrm{m}^{-2} \mathrm{~d}^{-1}\right)\end{array}$ & $\begin{array}{c}\text { FPC contribution to } \\
\text { POC sinking flux } \\
(\%)\end{array}$ \\
\hline \multirow[t]{3}{*}{ Amundsen Gulf } & $\begin{array}{l}\text { June } \\
2004\end{array}$ & I & $\begin{array}{c}35.4 \\
2.0-84.4\end{array}$ & $\begin{array}{c}0.24 \\
0-0.58\end{array}$ & $\begin{array}{c}35.6 \\
2.4-84.4\end{array}$ & $\begin{array}{c}33.7 \\
13.0-54.5\end{array}$ \\
\hline & $\begin{array}{l}\text { July to August } \\
2004\end{array}$ & II & $\begin{array}{c}14.9 \\
3.6-28.2\end{array}$ & $\begin{array}{c}0.16 \\
0-0.47\end{array}$ & $\begin{array}{c}15.0 \\
3.6-28.2\end{array}$ & $\begin{array}{c}27.3 \\
10.1-52.1\end{array}$ \\
\hline & $\begin{array}{c}\text { September to October } \\
2002 \text { and } 2003\end{array}$ & III & $\begin{array}{c}3.3 \\
1.9-5.0\end{array}$ & $\begin{array}{c}0.55 \\
0.12-1.3\end{array}$ & $\begin{array}{c}3.9 \\
2.8-6.1\end{array}$ & $\begin{array}{c}6.8 \\
4.3-8.4\end{array}$ \\
\hline \multirow[t]{3}{*}{$\begin{array}{l}\text { Mackenzie shelf } \\
\text { and slope }\end{array}$} & $\begin{array}{l}\text { July to August } \\
2004\end{array}$ & II & $\begin{array}{c}11.4 \\
7.0-20.1\end{array}$ & $\begin{array}{c}1.1 \\
0.1-2.1\end{array}$ & $\begin{array}{c}12.5 \\
7.4-21.1\end{array}$ & $\begin{array}{c}8.3 \\
5.8-10.8\end{array}$ \\
\hline & $\begin{array}{c}\text { September to October } \\
2002 \text { and } 2003\end{array}$ & III & $\begin{array}{c}1.8 \\
0.27-8.0\end{array}$ & $\begin{array}{c}0.29 \\
0.09-0.57\end{array}$ & $\begin{array}{c}2.1 \\
0.36-8.6\end{array}$ & $\begin{array}{c}3.9 \\
2.4-11.4\end{array}$ \\
\hline & Stn 65 in fall 2002 & IV & 8.0 & 0.57 & 8.6 & 11.4 \\
\hline \multirow[t]{2}{*}{ Franklin Bay } & July 2004 & & 84.0 & 2.0 & 86.0 & 75.7 \\
\hline & August 2004 & & 7.9 & 0.07 & 8.0 & 25.1 \\
\hline All regions & Average & & $\begin{array}{c}16.4 \\
0.27-84.4\end{array}$ & $\begin{array}{c}0.54 \\
0-2.1\end{array}$ & $\begin{array}{c}16.9 \\
0.36-86.0\end{array}$ & $\begin{array}{c}18.4 \\
2.4-75.7\end{array}$ \\
\hline
\end{tabular}


$\mathrm{d}^{-1}$ at $200 \mathrm{~m}$; Forest et al. 2007) and, for the most part, exceeded sinking fluxes previously reported across the same shelf area $\left(<80 \mathrm{mg} \mathrm{C} \mathrm{m}^{-2} \mathrm{~d}^{-1}\right.$ at 118 to $213 \mathrm{~m}$; $\mathrm{O}^{\prime}$ Brien et al. 2006). Both of these studies used longterm sediment trap moorings deployed well below the euphotic zone, and their lower sinking fluxes, compared to the present study, can be explained by a loss of sinking POC with depth (i.e. vertical flux attenuation) and/or methodological differences (i.e. short-term versus long-term deployments). Accordingly, Morata et al. (2008) found indications of high degradation of pigmented material prior to reaching the sediment. Nevertheless, a study of the benthic carbon demand in the eastern Beaufort Sea suggested a tight pelagicbenthic coupling and an annual benthic carbon demand of $\sim 12.1 \mathrm{~g} \mathrm{C} \mathrm{m}^{-2}$ on the shelf (Renaud et al. 2007a). This estimate agrees closely with our estimated POC sinking flux of $\sim 12.3 \mathrm{~g} \mathrm{C} \mathrm{m}^{-2}$ for the ice-free period, which is based on the average fluxes measured on the Mackenzie shelf and slope in July to August and September to October (see Table 2).

From a pan-Arctic perspective, the Beaufort Sea shelf showed lower POC sinking fluxes than reported for the extensively studied shelf of the central Barents Sea in spring and summer (range: ca. 250 to $850 \mathrm{mg} \mathrm{C} \mathrm{m}^{-2} \mathrm{~d}^{-1}$, between 40 and $60 \mathrm{~m}$; Wassmann 1989, Wassmann et al. 1990, Olli et al. 2002). The higher sinking fluxes reported in the Barents Sea is most likely a result of the higher annual primary production in this region (e.g. 25 to $30 \mathrm{~g} \mathrm{C} \mathrm{m}^{-2} \mathrm{yr}^{-1}$ in northern Barents Sea; Hegseth 1998) compared to the present study area (12 to $16 \mathrm{~g} \mathrm{C} \mathrm{m}^{-2} \mathrm{yr}^{-1}$; Carmack et al. 2004). The sinking fluxes in the present study are within the range of values reported from other short-term sediment trap studies during summer on the Chukchi Sea shelf (averages: 129 and $442 \mathrm{mg} \mathrm{C} \mathrm{m}^{-2} \mathrm{~d}^{-1}$, between 30 and $100 \mathrm{~m}_{\text {; Lalande et }}$ al. 2007), in the NOW (range: 142 to $554 \mathrm{mg} \mathrm{C} \mathrm{m}^{-2}$ $\mathrm{d}^{-1}$, between 50 and $150 \mathrm{~m}$; Caron et al. 2004), and during fall in the Hudson Bay system (range: 37.5 to $76.8 \mathrm{mg} \mathrm{C} \mathrm{m}^{-2} \mathrm{~d}^{-1}$, at $50 \mathrm{~m}$; Lapoussière et al. 2009), and are generally higher than those reported from the Kara Sea shelf and slope in fall (range: 0.5 to $185 \mathrm{mg} \mathrm{C} \mathrm{m} \mathrm{d}^{-1}$, between 9 and $360 \mathrm{~m}$; Wassmann et al. 2004), using sediment traps deployed for periods of 1 to $10 \mathrm{~d}$.

\section{Temporal and regional sinking export}

Although temporal trends could be confounded and possibly obscured by the limited number of stations visited and by regional and interannual variability, some general patterns emerged based on significant results from the clustering analysis.
A general decrease in the sinking export of chl a was observed in the eastern Beaufort Sea towards fall, i.e. from June to September-October (Table 2), indicating a decrease in the export of phytoplankton material from the euphotic zone. The 1 order of magnitude decrease in average chl a sinking fluxes from June to July-August in the Amundsen Gulf was also associated with a declining contribution of algal cells to POC sinking fluxes (from 11.7 to $7.6 \%$ in June and September to October; data not shown), estimated using a POC:chl a ratio of $40 \mathrm{~g}: \mathrm{g}$ from healthy algal cells (Lorenzen 1968). This agrees with the termination of a phytoplankton bloom during July in this region, as suggested by Simpson et al. (2008), based on decreasing integrated surface nitrate concentrations and phytoplankton biomass. The significantly lower export ratio in the Amundsen Gulf in June, compared to the following months (Table 2), is consistent with the biomass build-up during a phytoplankton bloom. Unfortunately, no sampling was carried out on the Mackenzie shelf and slope in June and we cannot comment on the chl a sinking export in this region at that time. However, the decrease in chl a sinking fluxes in this region from July-August to September-October was linked to decreased input by the river plume in fall compared to summer (Juul-Pedersen et al. 2008b). This decrease in the sinking export of algal material also represented a reduction of the algal contribution to sinking POC from July-August (17.0\%; data not shown) to September-October (10.2\%; data not shown), as estimated using the same POC:chl a ratio as above. Overall, the decrease in sinking export of chl $a$ and POC in the Amundsen Gulf and on the Mackenzie shelf and slope would have been driven by different regional processes, i.e. termination of the phytoplankton bloom and decreasing input from the river, respectively.

The retention of organic material within the euphotic zone was generally high throughout this study, as evidenced by low daily loss rates of chl a $\left(<4.0 \% \mathrm{~d}^{-1}\right)$ and POC $\left(<3.5 \% \mathrm{~d}^{-1}\right)$ (Table 2$)$. Daily loss rates of POC in our study are generally lower than those reported in Disko Bay, Greenland, in spring (from ca. 18 to $3 \% \mathrm{~d}^{-1}$ at 15 and $100 \mathrm{~m}$; Juul-Pedersen et al. 2006), while they compare with daily loss rates reported for the marginal ice zone in the Barents Sea during summer $\left(<4 \% \mathrm{~d}^{-1}\right.$ at $50 \mathrm{~m}$; Olli et al. 2002). Still, the POC sinking export accounted for a high proportion of the POC production by phytoplankton in the Amundsen Gulf, in summer and fall (>50\%; Table 2). In conjunction, the high retention of organic material and the high export in relation to primary production indicate that a small fraction of the suspended biomass was sinking to the benthos and that little additional biomass accumulation was taking place as more than half of the phytoplankton production was exported through sinking. 
A high transfer of organic material to the pelagic food web reduces the sinking export of high quality algal material, due to assimilation and remineralization, thus resulting in low daily loss rates of organic material, as observed in the Amundsen Gulf. These findings are in agreement with observations of a high biomass of herbivorous and omnivorous copepods in the Amundsen Gulf compared to the Mackenzie Shelf and slope (Darnis et al. 2008). The high fecal pellet sinking export and contribution of FPC to total POC sinking export in summer supports the strong influence of mesozooplankton on the suspended biomass. Grazing or destruction of fecal pellets by mesozooplankton (coprophagy or coprorhexy, respectively) may have contributed to the retention and remineralization of organic material in the pelagos, as reported for the Amundsen Gulf during sea ice cover (Sampei et al. 2009) and the Barents Sea during open water (e.g. Olli et al. 2002, Wexels Riser et al. 2007). Sampei et al. (2009) reported a sinking export attenuation of cylindrical fecal pellets produced in the epipelagic layer of up to $70 \%$ during sea ice cover in February. This is supported by the high abundance of broken and degraded fecal pellets in our samples (data not shown).

The zooplankton mediated sinking export was primarily due to copepods throughout this study, as cylindrical fecal pellets dominated the total FPC sinking fluxes (contributing on average ca. $90 \%$; Table 3). The observed percentage of cylindrical FPC (ca. 90\%) agrees closely with the percentage observed by Sampei et al. (2009) during incubation experiments (93\% of total FPC), although the different study periods have to be taken into consideration (ice cover versus open water). The extensive degradation of sinking cylindrical fecal pellets, as observed by these authors, explain why they found a strong dominance of elliptical fecal pellets at depth ( $75 \%$ of total FPC). A decrease in the fecal pellet contribution to total POC sinking fluxes was observed towards fall (i.e. from July-August to September-October), suggesting a lower grazing activity later in the season. Several Arctic copepod species have been shown to descend to depth to overwinter during summer and fall (e.g. Madsen et al. 2001), which may explain the decreasing trend in fecal pellet sinking fluxes towards fall. The generally higher FPC contribution to total POC sinking fluxes in the Amundsen Gulf, compared to the Mackenzie shelf and slope (Table 3 ), supports a higher grazing activity by the larger copepod biomass in this region (Darnis et al. 2008). Even more so, the station in Franklin Bay showed the highest fecal pellet contribution to total POC sinking fluxes observed during this study (ca. $76 \%$; Table 3), indicating a high transfer of organic material to pelagic grazers. Using the ingestion- egestion rate presented by Møller et al. (2003), i.e. $15 \%$ of POC removed from suspension by copepods is reintroduced into the water column as FPC, it is estimated that $573 \mathrm{mg} \mathrm{C} \mathrm{m}^{-2} \mathrm{~d}^{-1}$ was removed from suspension by grazers in Franklin Bay during July. The maximum fecal pellet carbon contribution to total POC observed throughout this study, particularly in the Amundsen Gulf (54.5\%) and in Franklin Bay $(75.7 \%$; Table 3), were similar to or exceeded some of the highest sinking fluxes reported from other Arctic areas (up to ca. $60 \%$; Riebesell et al. 1995, Wexels Riser et al. 2002, Sampei et al. 2004, Juul-Pedersen et al. 2006). Overall, these findings indicate an important transfer of sinking organic material through the large pelagic grazers, primarily copepods.

\section{Taxonomic composition of the sinking material}

The cluster-based analysis of the composition of the protist cell assemblage sinking out of the euphotic zone revealed clear temporal patterns which prevailed throughout the eastern Beaufort Sea (Fig. 3). The sinking protist (i.e. autotrophic and heterotrophic) assemblage from the euphotic zone was characterized by a dominance of flagellates and a decreasing diatom contribution from spring to fall (Fig. 4a). Flagellates often dominate during post-bloom conditions in Arctic waters, as diatom cells become nutrient limited (e.g. Rat'kova et al. 1998, Dale et al. 1999, Hill \& Cota 2005). The pennate diatom Fragilariopsis cylindrus, which was the dominant diatom species in June and July to August throughout the sampling area (Fig. 4b), is often associated with sea ice, although it has been found to be abundant and productive in cold marine waters as well (von Quillfeldt 2004). In the NOW, high sinking fluxes of $F$. cylindrus cells were linked to the spring phytoplankton bloom in June (Caron et al. 2004). F. cylindrus was also present in the water column during this study (M. Poulin pers. comm.). In our study area, a parallel study on ice algal composition found Nitzschia spp., Navicula spp. and F. cylindrus to be the dominant microalgal taxa in bottom landfast first-year sea ice in Franklin Bay (Różańska et al. 2009). An input of algae from the sea ice is thus inferred from the presence of the pennate diatoms Nitzschia frigida, Navicula vanhoeffenii and F. cylindrus in June and July to August, and their minor contribution to the sinking assemblage in September to October (Fig. 4b). These pennate diatoms are considered as typical ice algal species (e.g. Sakshaug 2004, Michel et al. 2006, Różańska et al. 2009).

The increasing contribution of Chaetoceros spp. and other centric diatoms to the diatom sinking assemblage in September to October is consistent with the seasonal phytoplankton species succession reported for Fro- 
bisher Bay (Hsiao 1992) and for the sinking diatom assemblage in the NOW (Caron et al. 2004). The fact that centric diatom spores were only observed in July to August and September to October (Fig. 4c) agrees with nitrate depletion during summer and fall, as suggested by Simpson et al. (2008). The production of diatom resting spores has been linked to nutrient limitation (e.g. Hargraves \& French 1983). Interestingly, empty diatom frustules were an abundant part of the material exported from the euphotic zone throughout this study (Fig. 4c), contributing on average $\sim 3$ times as much, by number, as intact diatom cells (data not shown). A significant degradation of diatom cells thus appeared to have occurred within the euphotic zone. Altogether, the cluster-based analysis revealed a general seasonal phytoplankton species succession similar to that of other high-latitude coastal waters (e.g. Dale et al. 1999). The analysis also revealed the strong influence of the Mackenzie River, as discussed in JuulPedersen et al. (2008b), since the cell assemblage of Stn 65 formed a distinctive group comprising the freshwater pennate diatom Eunotia sp. Both the observed seasonal phytoplankton species succession and the influence of the Mackenzie River support parallel patterns observed in sedimentary pigments of the region (Morata et al. 2008).

\section{A landfast sea ice perspective}

In contrast with the adjacent Amundsen Gulf, Franklin Bay is characterized by a prolonged landfast firstyear sea ice cover. The time-series obtained at this location, from March to August, illustrates the importance of landfast spring melt for the sinking export of chl $a$ and POC (Fig. 5). The under-ice sinking export of chl $a$ and POC, during landfast spring melt (averaging 0.7 and $115.4 \mathrm{mg} \mathrm{m}^{-2} \mathrm{~d}^{-1}$ in June, respectively; Fig. 5), was similar to the highest open water sinking fluxes recorded in the eastern Beaufort Sea, during this study (Table 2).

The sinking fluxes of chl $a$ and POC observed during open water sampling in Franklin Bay, in July and August, were within the ranges of sinking fluxes observed in the Amundsen Gulf at the same time (i.e. July to August; Table 2). The similarities between these 2 areas indicate consistency in regional patterns of particulate organic material sedimentation during ice-free conditions in the entire Amundsen Gulf region (including Franklin Bay), which also agrees with the widespread temporal progression in taxonomic composition of sinking protist assemblages observed during our study (i.e. cluster-based analysis).

The transition from ice-covered (i.e. from March to June) to open waters (i.e. in July and August) in
Franklin Bay (Fig. 5, Tables 2 \& 3) reveals a seasonal shift in sinking export processes. The high chl $a$ and POC sinking export in June during the landfast spring melt was attributed to the release of ice-associated biomass into the underlying water column, as described by Juul-Pedersen et al. (2008a). A parallel study found that the sinking of ice algae during the landfast spring melt may represent an important cue for the seasonal increase in benthic activity and oxygen demand in Franklin Bay (Renaud et al. 2007b). In contrast, the material collected during open water sampling in July reflected a POC sinking export largely related to copepod grazing activity, as FPC made up most of the sinking POC (Table 3). It therefore appears that copepods played a key role in the remarkably high export of phytoplankton primary production in July (export ratio of ca. $97 \%$; Table 2), diverting most of the primary produced organic material through the pelagic heterotrophic food web. The high grazing activity following sea ice melt is thought to be the result of the already active copepod community observed during the sea ice cover in Franklin Bay (Sampei et al. 2009). Copepod grazing activity and sinking export of phytoplankton primary production, as reflected by FPC sinking fluxes and the export ratio (Tables 2 \& 3), decreased substantially from July to August. Overall, the high sinking export of ice-associated material released during the landfast spring melt appeared to have been followed soon after by a peak in copepod grazing activity.

\section{SUMMARY AND CONCLUSION}

The extensive spatial and temporal study of the sinking export of particulate organic material from the euphotic zone showed similar chl $a$ and POC sinking fluxes throughout the eastern Beaufort Sea in fall. In summer, higher sinking fluxes of POC were observed on the Mackenzie shelf and slope than in the Amundsen Gulf. Overall, a decrease was observed in the sinking export of chl $a$ and POC from spring to fall. Daily loss rates of chl $a$ and POC were low throughout this study $\left(<4 \% \mathrm{~d}^{-1}\right)$, while the Amundsen Gulf showed a high export ratio of particulate phytoplankton production during summer (ca. 50\%). Zooplankton played an important role in the sinking export of particulate organic material, particularly in the Amundsen Gulf. The cluster-based analysis of the sinking protist cell assemblage revealed a seasonal succession that prevailed over spatial and interannual differences amongst sampling stations. A considerable diatom contribution to the sinking assemblage, dominated by the pennate diatom Fragilariopsis cylindrus, in summer was followed by a dominance of flagellated cells towards fall. Input from the sea ice at the stations vis- 
ited in summer (June to July) was shown by the presence of ice diatoms Nitzschia frigida and Navicula vanhoeffenii in the sinking material. The high chl $a$ and POC sinking fluxes measured during the landfast spring melt emphasize the importance of including the spring melt period when studying sinking export in Arctic regions.

Acknowledgements. The authors thank B. LeBlanc, K. Cherewyk, K. Wilson, M. Poulin, D. Bérubé, M. Simard, J. Ferland and other collaborators for their assistance with the field and laboratory work. We express our gratitude to S. Brugel and $\mathrm{S}$. Demers for providing suspended $\mathrm{chl} a$ and primary production data. We are grateful to Y. Gratton for providing irradiance data. We thank K. Proteau for protist cell counts and identification. We also thank the 2 anonymous reviewers for their most helpful suggestions for improving this paper. We acknowledge the officers and crew onboard the CCGS 'Amundsen' for their support during the field work and the Canadian Arctic Shelf Exchange Study (CASES) for providing the opportunity for this study. Financial support was provided by the Natural Sciences and Engineering Research Council (NSERC) of Canada (research Network grant and Discovery grant to C.M. and M.G.) and from the Department of Fisheries and Oceans Canada (Strategic Research Fund to C.M.). Partial operating funds for the CCGS 'Amundsen' were provided by the International Joint Ventures Fund of the Canada Foundation for Innovation and the Fonds québécois de la recherche sur la nature et les technologies (FQRNT). T.J.-P. received post-graduate scholarships from the Institut des sciences de la mer de Rimouski (ISMER) and Université du Québec à Rimouski. This publication is a contribution to the research programs of CASES, the Freshwater Institute (Fisheries and Oceans Canada), ISMER and Québec-Océan.

\section{LITERATURE CITED}

ACIA (2005) Arctic climate impact assessment. Cambridge University Press, Cambridge

Amiel D, Cochran JK (2008) Terrestrial and marine POC fluxes derived from ${ }^{234} \mathrm{Th}$ distributions and $\delta^{13} \mathrm{C}$ measurements on the Mackenzie Shelf. J Geophys Res 113: C03S06. doi:10.1029/2007JC004260

Amiel D, Cochran JK, Hirschberg DJ (2002) ${ }^{234} \mathrm{Th} /{ }^{238} \mathrm{U}$ disequilibrium as an indicator for the seasonal export flux of particulate organic carbon in the North Water. Deep-Sea Res II 49:5191-5209

Arrigo KR, van Dijken GL (2004) Annual cycles of sea ice and phytoplankton in Cape Bathurst polynya, southeastern Beaufort Sea, Canadian Arctic. Geophys Res Lett 31: L08304, doi:10.1029/2003GL018978

Arrigo KR., van Dijken G, Pabi S (2008) Impact of a shrinking Arctic ice cover on marine primary production. Geophys Res Lett 35:L19603, doi:1029/2008GL035028

Barber DG, Hanesiak JM (2004) Meteorological forcing of sea ice concentration in the southern Beaufort Sea over the period 1979 to 2000. J Geophys Res 109:C06014, doi: 10.1029/2003JC0022027

Belchansky GI, Douglas DC, Eremeev VA, Platonov NG (2005) Variations in the Arctic's multiyear sea ice cover: a neural network analysis of SMMR-SSM/I data, 19792004. Geophys Res Lett 32:L09605. doi:10.1029/2005GL022395

Brugel S, Nozais C, Poulin M, Tremblay JÉ and others (2009)
Phytoplankton biomass and production in the southeastern Beaufort Sea in autumn 2002 and 2003. Mar Ecol Prog Ser 377:63-77

Carmack EC, Macdonald RW (2002) Oceanography of the Canadian Shelf of the Beaufort Sea: A setting for marine life. Arctic 55:29-45

Carmack E, Wassmann P (2006) Food webs and physical-biological coupling on pan-Arctic shelves: Unifying concepts and comprehensive perspectives. Prog Oceanogr 71: 446-477

Carmack EC, Macdonald RW, Jasper S (2004) Phytoplankton productivity on the Canadian Shelf of the Beaufort Sea. Mar Ecol Prog Ser 277:37-50

> Carmack E, Barber D, Christensen J, Macdonald R, Rudels B, Sakshaug E (2006) Climate variability and physical forcing of the food webs and the carbon budget on panarctic shelves. Prog Oceanogr 71:145-181

Caron G, Michel C, Gosselin M (2004) Seasonal contributions of phytoplankton and fecal pellets to the organic carbon sinking flux in the North Water (northern Baffin Bay). Mar Ecol Prog Ser 283:1-13

Clarke KR, Gorley RN (2001) PRIMER v5 User manual/tutorial. PRIMER-E, Plymouth

Dale T, Rey F, Heimdal BR (1999) Seasonal development of phytoplankton at a high latitude oceanic site. Sarsia 84 : 419-435

> Darnis G, Barber D, Fortier L (2008) Sea ice and the onshoreoffshore gradient in pre-winter zooplankton assemblages in southeastern Beaufort Sea. J Mar Syst 74:994-1011

> Dittmar T, Kattner G (2003) The biogeochemistry of the river and shelf ecosystem of the Arctic Ocean: a review. Mar Chem 83:103-120

Field JG, Clarke KR, Warwick RM (1982) A practical strategy for analysing multispecies distribution patterns. Mar Ecol Prog Ser 8:37-52

> Forest A, Sampei M, Hattori H, Makabe R and others (2007) Particulate organic carbon fluxes on the slope of the Mackenzie Shelf (Beaufort Sea): Physical and biological forcing of shelf-basin exchanges. J Mar Syst 68:39-54

Fortier M, Fortier L, Michel C, Legendre L (2002) Climatic and biological forcing of the vertical flux of biogenic particles under seasonal Arctic sea ice. Mar Ecol Prog Ser 225: $1-16$

Gardner WD (2000) Sediment trap sampling in surface waters: issues and recommendations. In: Hanson RB, Ducklow HW, Field JG (eds) The changing ocean carbon cycle: a midterm synthesis of the Joint Global Ocean Flux Study. Cambridge University Press, Cambridge, p 240-281

González HE, González SR, Brummer GJA (1994) Short-term sedimentation pattern of zooplankton, faeces and microplankton at a permanent station in the Bjørnafjorden (Norway) during April-May 1992. Mar Ecol Prog Ser 105: $31-45$

> Gosselin M, Levasseur M, Wheeler PA, Horner RA, Booth BC (1997) New measurements of phytoplankton and ice algae production in the Arctic Ocean. Deep-Sea Res II 44: 1623-1644

Grebmeier JM, Cooper LW, Feder HM, Sirenko BI (2006) Ecosystem dynamics of the Pacific-influenced Northern Bering and Chukchi Seas in the Amerasian Arctic. Prog Oceanogr 71:331-361

Hargraves PE, French FW (1983) Diatom resting spores: Significance and strategies. In: Fryxell GA (ed) Survival strategies of the algae. Cambridge University Press, New York, p 49-68

$>$ Hegseth EN (1998) Primary production of the northern Barents Sea. Polar Res 17:113-123 
Hill V, Cota G (2005) Spatial patterns of primary production on the shelf, slope and basin of the Western Arctic in 2002. Deep-Sea Res II 52:3344-3354

Hsiao SIC (1992) Dynamics of ice algae and phytoplankton in Frobisher Bay. Polar Biol 12:645-651

IPCC (2007) Climate change 2007: The physical science basis. Contribution of Working Group I to the Fourth Assessment Report of the Intergovernmental Panel on Climate Change. Cambridge University Press, Cambridge and New York

Jakobsson M (2002) Hypsometry and volume of the Arctic Ocean and its constituent seas. Geochem Geophys Geosyst 3:1-18, doi:10.1029/2001GC000302

> Juul-Pedersen T, Nielsen TG, Michel C, Møller EF and others (2006) Sedimentation following the spring bloom in Disko Bay, West Greenland, with special emphasis on the role of copepods. Mar Ecol Prog Ser 314:239-255

Juul-Pedersen T, Michel C, Gosselin M (2008a) Seasonal changes in the sinking export of particulate material under first-year sea ice on the Mackenzie Shelf (western Canadian Arctic). Mar Ecol Prog Ser 353:13-25

Juul-Pedersen T, Michel C, Gosselin M (2008b) Influence of the Mackenzie River plume on the sinking export of particulate material on the shelf. J Mar Syst 74:810-824

Klein B, LeBlanc B, Mei ZP, Beret R and others (2002) Phytoplankton biomass, production and potential export in the North Water. Deep-Sea Res II 49:4983-5002

Knap A, Michaels A, Close A, Ducklow H, Dickson A (1996) Protocols for the Joint Global Ocean Flux Study (JGOFS) Core Measurements JGOFS Report Nr. 19. Reprint of the IOC Manuals and Guides No. 29, UNESCO, Bergen

> Lalande C, Grebmeier JM, Wassmann P, Cooper LW, Flint MV, Sergeeva VM (2007) Export fluxes of biogenic matter in the presence and absence of seasonal sea ice cover in the Chukchi Sea. Cont Shelf Res 27:2051-2065

Lapoussière A, Michel C, Gosselin M, Poulin M (2009) Spatial variability in organic material sinking export in the Hudson Bay system, Canada, during fall. Cont Shelf Res 29: 1276-1288

Lean DRS, Burnison BK (1979) An evaluation of errors in the ${ }^{14} \mathrm{C}$ method of primary measurement. Limnol Oceanogr 24:917-928

Legendre P, Legendre L (1998) Numerical ecology, 2nd edn. Elsevier Science BV, Amsterdam

Legendre L, Ackley SF, Dieckmann GS, Gulliksen B and others (1992) Ecology of sea ice biota. 2 Global significance. Polar Biol 12:429-444

> Lorenzen CJ (1968) Carbon/chlorophyll relationships in an upwelling area. Limnol Oceanogr 13:202-204

Lund JWG, Kipling C, Le Cren ED (1958) The inverted microscope method of estimating algal numbers and the statistical analysis of estimations by counting. Hydrobiologia 11: $143-170$

Macdonald RW, Solomon SM, Cranston RE, Welch HE, Yunker MB, Gobeil C (1998) A sediment and organic carbon budget for the Canadian Beaufort Sea. Mar Geol 144: 255-273

Madsen SD, Nielsen TG, Hansen BW (2001) Annual population development and production by Calanus finmarchicus, C. glacialis and C. hyperboreus in Disko Bay, western Greenland. Mar Biol 139:75-93

> Maslanik JA, Fowler C, Stroeve J, Drobot S, Zwally J, Yi D, Emery W (2007) A younger, thinner Arctic ice cover: Increased potential for rapid, extensive sea-ice loss. Geophys Res Lett 34:L24501. doi:10.1029/2007GL032043

> Michel C, Legendre L, Ingram RG, Gosselin M, Levasseur M (1996) Carbon budget of sea-ice algae in spring: Evidence of a significant transfer to zooplankton grazers. J Geophys Res 101:18345-18360

Michel C, Gosselin M, Nozais C (2002) Preferential sinking export of biogenic silica during the spring and summer in the North Water Polynya (northern Baffin Bay): Temperature or biological control? J Geophys Res 107:3064, doi:10. 1029/2002JC000408

Michel C, Ingram RG, Harris LR (2006) Variability in oceanographic and ecological processes in the Canadian Arctic Archipelago. Prog Oceanogr 71:379-401

Møller EF, Thor P, Nielsen TG (2003) Production of DOC by Calanus finmarchicus, C. glacialis and C. hyperboreus through sloppy feeding and leakage from fecal pellets. Mar Ecol Prog Ser 262:185-191

Morata N, Renaud PE, Brugel S, Hobson KA, Johnson BJ (2008) Spatial and seasonal variations in the pelagic-benthic coupling of the southeastern Beaufort Sea revealed by sedimentary biomarkers. Mar Ecol Prog Ser 371:47-63

Mundy CJ, Gosselin M, Ehn J, Gratton Y and others (2009) Contribution of under-ice primary production to an iceedge upwelling phytoplankton bloom in the Canadian Beaufort Sea. Geophys Res Lett 36:L17601. doi:10.1029/ 2009GL038837

O'Brien MC, Macdonald RW, Melling H, Iseki K (2006) Particle fluxes and geochemistry on the Canadian Beaufort Shelf: Implications for sediment transport and deposition. Cont Shelf Res 26:41-81

Olli K, Wexels Riser C, Wassmann P, Rat'kova T, Arashkevich E, Pasternak A (2002) Seasonal variation in vertical flux of biogenic matter in the marginal ice zone and the central Barents Sea. J Mar Syst 38:189-204

Parsons TR, Maita Y, Lalli CM (1984) A manual of chemical and biological methods for seawater analysis. Pergamon Press, Toronto

Rat'kova TN, Wassmann P, Verity P, Andreassen IJ (1998) Abundance and biomass of pico-, nano-, and microplankton on a transect across Nordvestbanken, north Norwegian shelf, in 1994. Sarsia 84:213-225

> Renaud PE, Morata N, Ambrose WG Jr, Bowie JJ, Chiuchiolo A (2007a) Carbon cycling by seafloor communities on the eastern Beaufort Sea shelf. J Exp Mar Biol Ecol 349: $248-260$

Renaud PE, Riedel A, Michel C, Morata N, Gosselin M, JuulPedersen T, Chiuchiolo A (2007b) Seasonal variation in benthic community oxygen demand: A response to an ice algal bloom in the Beaufort Sea, Canadian Arctic? J Mar Syst 67:1-12

Riebesell U, Reigstad M, Wassmann P, Noji T, Passow U (1995) On the trophic fate of Phaeocystis pouchetii (Hariot): VI. Significance of Phaeocystis-derived mucus for vertical flux. Neth J Sea Res 33:193-203

> Różańska M, Gosselin M, Poulin M, Wiktor JM, Michel C (2009) Influence of environmental factors on the development of bottom ice protist communities during the winter-spring transition. Mar Ecol Prog Ser 386:43-59

Sakshaug E (2004) Primary and secondary production in the Arctic Seas. In: Stein R, Macdonald RW (eds) The organic carbon cycle in the Arctic Ocean. Springer, Berlin, p 57-82

Sakshaug E, Skjoldal HR (1989) Life at the ice edge. Ambio 18:60-67

> Sampei M, Sasaki H, Hattori H, Fukuchi M, Hargrave BT (2004) Fate of sinking particles, especially fecal pellets, within the epipelagic zone in the North Water (NOW) polynya of northern Baffin Bay. Mar Ecol Prog Ser 278: $17-25$

Sampei M, Forest A, Sasaki H, Hattori H, Makabe R, Fukuchi M, Fortier L (2009) Attenuation of the vertical flux of cope- 
pod fecal pellets under Arctic sea ice: evidence for an active detrital food web in winter. Polar Biol 32:225-232

Simpson KG, Tremblay JÉ, Gratton Y, Price NM (2008) An annual study of inorganic and organic nitrogen and phosphorus and silicic acid in the southeastern Beaufort Sea. J Geophys Res 113:C07016. doi:10.1029/2007JC004462

Sokal RR, Rohlf FJ (1981) Biometry: the principles and practice of statistics in biological research, 2nd edn. WH Freeman, San Francisco, CA

Stein R, Macdonald RW (2004) The organic carbon cycle in the Arctic Ocean. Springer, New York

Subba Rao DV, Platt T (1984) Primary production of Arctic waters. Polar Biol 3:191-201

Tremblay JÉ, Hattori $\mathrm{H}$, Michel $\mathrm{C}$, Ringuette $\mathrm{M}$ and others (2006) Trophic structure and pathways of biogenic carbon flow in the eastern North Water Polynya. Prog Oceanogr 71:402-425

Turner JT (2002) Zooplankton fecal pellets, marine snow and sinking phytoplankton blooms. Aquat Microb Ecol 27: 57-102

von Quillfeldt CH (2004) The diatom Fragilariopsis cylindrus and its potential as an indicator species for cold water rather than for sea ice. Vie Milieu 54:137-143

Editorial responsibility: Graham Savidge,

Portaferry, UK
Wassmann P (1989) Sedimentation of organic matter and silicate from the euphotic zone of the Barents Sea. Rapp P-V Reun Cons Int Explor Mer 188:108-114

> Wassmann P, Vernet M, Mitchell BG, Rey F (1990) Mass sedimentation of Phaeocystis pouchetii in the Barents Sea. Mar Ecol Prog Ser 66:183-195

Wassmann P, Bauerfeind E, Fortier M, Fukuchi M and others (2004) Particulate organic carbon flux to the Arctic Ocean sea floor. In: Stein R, Macdonald RW (eds) The organic carbon cycle in the Arctic Ocean. Springer, Berlin, p 101-138

Wassmann P, Reigstad M, Haug T, Rudels B and others (2006) Food webs and carbon flux in the Barents Sea. Prog Oceanogr 71:232-287

Wexels Riser C, Wassmann P, Olli K, Pasternak A, Arashkevich E (2002) Seasonal variation in production, retention and export of zooplankton faecal pellets in the marginal ice zone and central Barents Sea. J Mar Syst 38:175-188

Wexels Riser C, Reigstad M, Wassmann P, Arashkevich E, Falk-Petersen S (2007) Export or retention? Copepod abundance, faecal pellet production and vertical flux in the marginal ice zone through snap shots from the northern Barents Sea. Polar Biol 30:719-730

Submitted: June 5, 2009; Accepted: April 2, 2010

Proofs received from author(s): June 30, 2010 